\title{
UPAYA PENINGKATAN KEAKTIFAN BELAJAR DAN KETERAMPILAN TENIS MEJA MENGGUNAKAN METODE LATIHAN
}

\author{
Tinuk Suprihatin \\ SD Negeri 6 Baturetno \\ endang3winarni@gmail.com
}

\begin{abstract}
Abstrak
Penelitian ini bertujuan untukmeningkatkan keaktifan belajar dan keterampilan tenis meja menggunakan metode latihan pada Siswa Kelas V SD Negeri 6 Baturetno Kecamatan Baturetno Kabupaten Wonogiri Tahun Pelajaran 2019/2020. Jenis penelitian ini yaitu penelitian tindakan kelas, dengan subyek penelitian yaitu siswa kelas VI SD Negeri 6 Baturetno semester II Tahun Pelajaran 2019/2020. Teknik pengumpulan data pada penelitian ini yaitu observasi, tes, angket dan dokumentasi. Prosedur penelitian terdiri dari 2 siklus dengan langkah-langkah meliputi perencanaan, pelaksanaan, evaluasi dan refleksi. Indikator kinerja meliputi hasil observasi tentang aktifitas belajar siswa dan tes keterampilan bermain tenis meja dengan menggunakan test unjuk kerja. Hasil penelitian diperoleh keterangan bahwa metode latihan dapat meningkatkan keaktifan belajar dan keterampilan tenis meja pada siswa kelas VI SD Negeri 6 Baturetno Kecamatan Baturetno Kabupaten Wonogiri Tahun Pelajaran 2019/2020.
\end{abstract}

Kata kunci: Aktifitas Belajar, keterampilan tenis meja, metode latihan

\begin{abstract}
This study aims to increase learning activeness and table tennis skills using the training method for Class V SD Negeri 6 Baturetno, Baturetno District, Wonogiri Regency, 2019/2020 Academic Year. This type of research is classroom action research, with the research subjects namely students of class VI SD Negeri 6 Baturetno semester II of the 2019/2020 academic year. Data collection techniques in this study are observation, tests, questionnaires and documentation. The research procedure consisted of 2 cycles with steps including planning, implementing, evaluating and reflecting. Performance indicators include the results of observations about student learning activities and skills tests to play table tennis using performance tests. The results obtained information that the training method can improve learning activeness and table tennis skills in grade VI SD Negeri 6 Baturetno, Baturetno District, Wonogiri Regency, 2019/2020 Academic Year.
\end{abstract}

Keywords: Learning activities, table tennis skills, training methods

\section{PENDAHULUAN}

Pendidikan Jasmani pada dasarnya merupakan bagian integral dari sistem pendidikan secara keseluruhan, bertujuan untuk mengembangkan aspek kesehatan, kebugaran jasmani, keterampilan berfikir kritis, stabilitas emosional, keterampilan sosial, penalaran dan tindakan moral melalui aktivitas jasmani dan olahraga. Selaras dengan itu Subagya menyatakan bahwa : Secara umum tujuan pendidikan jasmnai di sekolah dasar adalah memacu pertumbuhan dan perkembangan jasmani, mental, emosional, dan sosial yang selaras dalam upaya membentuk dan mengembangkan kemampuan gerak dasar, menanamkan nilai, sikap, dan mebiasakan hidup sehat (Subagiyo, 2008: 107).

Sedangkan tujuan pendidikan jasmani harus sesuai dengan tujuan pendidikan nasional. Salah satu tujuan pendidikan nasional seperti yang tertuang dalam UUD 1945 adalah untuk membentuk manusia Indonesia yang sehat jasmani dan rohani. Dengan demikian maka mata pelajaran Penjasorkes mempunyai peran utama untuk membentuk dan meningkatkan kesegaran jasmani peserta didiknya dalam rangka mencapai tujuan pendidikan nasional. 
Salah satu materi dari mata pelajaran pendidikan jasmani yang diberikan di Kelas VI Sekolah Dasar sesuai dengan Kurikulum Tingkat Satuan Pendidikan Dasar Negeri 6 Baturetno yang diberikan pada semester II. adalah permainan tenis meja Materi pelajaran permainan tenis meja merupakan materi yang sangat penting untuk dikuasai siswa sebab dengan bermain tenis meja bisa melatih kerja otak . Ketika bermain tenis meja biasa bekerja lebih cepat karena saat bermain harus degan cepat mengambil keputusan dan berpikir strategi apa yang akan dilakukan misalnya setelah servis apa yang akan kita lakukan, kemana arah yang diincar, servis pendek atau panjang, dan masih banyak lainnya. Tanpa disadari akan menjadi seseorang pemikir yang cukup serius karena jika terus-menerus bermain tenis meja maka keahlian dalam berpikir serta mengambil keputusan akan berkembang dengan baik. Dengan terlatihnya kerja otak siswa maka siswa akan menjadi cerdas dan terampil. Hal ini sangat sesuai dengan tujuan pendidikan nasional sebagaimana dituangkan dalam UU No 30 Tahun 2003 tentang Sistem Pendidikan Nadional.

Begitu pentingnya permainan tenis meja dalam membentuk siswa cerdas dan terampil sehingga guru penjasorkes SDN 6 Baturetno telah berupaya agar siswa mampu bermain tenis meja dengan terampil, yakni dengan memberikan penjelasan serta memberi contoh berbagai gerakan diantaranya tentang teknis memegang bet yang benar, teknis memukul bola yang benar, posisi badan sampai dengan gerakan kaki, dan siswapun telah diberi kesempatan untuk memperhatikan dan mencoba menirukan gerakan sebagaimana dicontohkan guru, namun ketika ditugasi untuk praktik di lapangan dengan menggunakan media meja pingpong, ternyata hasilnya masih belum sesuai harapan. Gerakan tangan dan badan masih kaku, posisi tubuh belum benar dan pukulan bolapun belum menyasar pada tujuan. Kondisi tersebut menunjukkan bahwa keterampilan bermain tenis meja bagi siswa kelas VI SDN 6 Baturetno ini masih rendah.

Rendahnya keterampilan bermain tenis meja siswa kelas VI SDN 6 Baturetno pada semester I (dua) tahun pelajaran 2019/2020 ini ditunjukkan dari hasil penilaian praktik tenes meja dari 21 siswa baru 8 siswa $(38,1 \%)$ yang tuntas belajar terdiri dari 1 siswa $(4,76 \%)$ mendapatkan nilai 85 atau dalam kategori baik dan 4 siswa $(19,04 \%)$ mendapat nilai 80 atau dalam kategori baik, 3 siswa $(14,28 \%)$ mendapat nilai 75 atau dalam kategori cukup, dan yang lainnya (13 siswa) atau $61,9 \%$ masih di bawah KKM, atau dalam kategori kurang. Untuk rata-rata kelas sebesar 61,43 termasuk dalam kategori kurang.

Proses pembelajaran yang telah dilakukan guru di atas kiranya menjadi faktor penyebab rendahnya keterampilan bermain tenis meja siswa, karena terbutki belum berhasil mewujudkan harapan yang diinginkan. Proses pembelajaran dengan memberikan penjelasan beserta contoh gerakan dan siswa diberi kesempatan untuk menirukan, namun tidak memberi kesempatan siswa untuk berlatih. Siswa hanya menirukan contoh guru, dan ketika guru tidak memberi contoh siswa hanya diam, seolah-olah tidak memiliki inisiatif untuk berlatih, sehingga siswa hanya pasif, dan menunggu aba-aba dari guru.

Mengingat begitu pentingnya materi permainan tenis meja ini bagi siswa maka guru berupaya untuk mencarikan solusi agar keterampilan bermain tenis meja bisa meningkat. Upaya yang dilakukan guru adalah dengan menggunakan drill method atau metode latihan. Dengan menggunakan metode latihan siswa dapat melakukan latihan secara berulang-ulang sehingga siswa menjadi terbiasa melakukan gerakan-gerakan tersebut dan 
pada akhirnya akan terbentuk keterampilan siswa dalam bermain tenis meja. Hal ini sesuai dengan pendapat ahli (Roestiyah, 2008) yang menyatakan bahwa dalam pembelajaran di sekolah khususnya dalam mata pelajaran pendidikan jasmani, metode drill (latihan) baik digunakan dalam melatih keterampilan berolahraga. Dengan melakukan latihan secara berulang-ulang pemahaman siswa lebih banyak dan siswa siap menggunakan keterampilannya karena sudah dibiasakan.

Penggunaan metode latihan dalam meningkatkan keterampilan bermain tenis meja ini didukung juga oleh penelitian yang relevan dengan penelitian ini yakni penelitian yang dilakukan oleh Suwaji,S.Pd, 2013 yang berjudul Peningkatan Keterampilan Bermain Sepak Bola Melalui Driil Method Kelas V Semester 1 di SD Negeri III Belikurip Kabupaten Wonogiri Tahun Ajaran 2013/2014. Penelitian tindakan kelas dilakukan di SD Negeri III Belikurip Kabupaten Wonogiri. Waktu penelitian dilakukan pada semester I tahun pelajaran 2013/2014. Subyek pada penelitian tindakan kelas ini adalah keseluruhan siswa yang ada di kelas $\mathrm{V}$ (Lima) Semester 1 (Satu) di SD Negeri III Belikurip Kabupaten Wonogiri Tahun Ajaran 2013/2014. Hasil penelitian ini adalah pada kegiatan setiap tindakan yang dilakukan oleh peneliti mampu meningkatkan hasil belajar siswa. Hal ini ditunjukkan dengan besarnya peningkatan nilai rata-rata kegiatan prasiklus ke siklus I sebesar 4,44 dengan jumlah ketuntasan meningkat sebanyak 3 siswa $(20,00 \%)$.

Peningkatan nilai rata-rata pada kegiatan siklus I ke siklus II sebesar 5,56 dengan jumlah ketuntasan meningkat sebanyak 4 siswa $(26,67 \%)$. Peningkatan nilai rata-rata pada kegiatan siklus II ke siklus III sebesar 6,67 dengan jumlah ketuntasan meningkat sebanyak 2 siswa $(13,33 \%)$. Hal ini menunjukkan bahwa dengan menerapkan metode drill method, siswa kelas V SD Negeri 6 Baturetno dalam proses pembelajaran Pendidikan Jasmani, Olahraga dan Kesehatan dalam materi pokok permainan sepak bola mampu meningkatkan hasil belajar siswa.

Kesamaan penelitian di atas dengan penelitian yang guru lakukan adalah samasama menggunakan metode berlatih dalam meningkatkan keterampilan dalam olahraga permainan. Perbedaannya ada pada materi pelajaran, dalam penelitian ini adalah pada permainan tenis meja sedangkan pada penelitian terdahulu materinya bermain sepak bola.

\section{METODE PENELITIAN}

Penelitian dilaksanakan selama 5 bulan, mulai dari bulan Juli sampai dengan November 2019. Penelitian dilaksanakan di SDN 6 Baturetno, Kecamatan Baturetno, Kabupaten Wonogiri, pada siswa kelas VI (Enam) semester 1 tahun pelajaran 2019/2020. Penentuan tempat penelitian dengan mempertimbangkan beberapa hal diantaranya, 1). Dalam melaksanakan kegiatan penelitian tidak meninggalkan tugas; 2). pelaksanaan penelitian berpengaruh terhadap proses pembelajaran di kelas VI.

Subyek penelitian ini adalah siswa kelas VI SDN 6 Baturetno Semester 1 tahun pelajaran 2019/2020. Jumlah siswa ada 21 (dua puluh satu) anak terdiri dari 12 (dua belas) anak laki-laki dan 9 (sembilan) anak perempuan dalam satu rombongan belajar. Obyek penelitian adalah aktivitas dan keterampilan bermain tenis meja. Sementara itu, teknik pengumpulan data yang digunakan yaitu dokumen, tes tertulis, wawancara, dan observasi.

$$
\text { Penelitian direncanakan }
$$
menggunakan tindakan daur ulang seperti yang dikembangkan oleh Suharsimi Arikunto (2010:17) dengan menggunakan langkah-langkah: perencanaan, pelaksanaan, pengamatan dan refleksi. Penelitian 
dilaksanakan dalam dua siklus dengan gambaran model sebagai berikut:

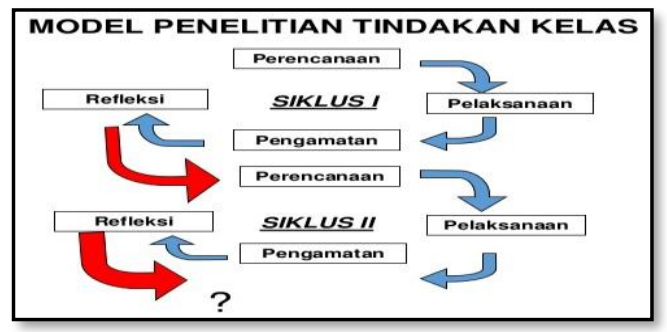

Gambar 1. Pelaksanaan Tindakan dalam Dua Siklus

Pada bagian akhir penelitian tindakan kelas ini telah ditentukan target yang akan dicapai sebagai berikut:

\section{Proses Pembelajaran Siswa}

Target yang ingin dicapai pada proses pembelajaran penelitian ini adalah dari pembelajaran yang dalan kategori cukup menjadi menjadi pembelajaran yang berkategori baik. Kategori proses pembelajaran berdasarkan prosentase banyaknya siswa yang aktif dalam mengikuti pembelajaran. Berikut ini kategori proses pembelajaran siswa : 1) Kurang Baik < $25 \%$, 2) Cukup $26 \%$ - $49 \%$, 3) Baik $50 \%$ - $75 \%$, 4) Sangat Baik $76 \%$ $100 \%$. Target yang diharapkan rata-rata persentase keaktifan siswa mencapai $86 \%$ atau dari jumlah 21 siswa kelas VI, terdapat siswa yang keaktifan belajarnya berkategori minimal baik sebanyak 12 orang.

\section{Keaktifan Belajar Siswa}

Target keaktifan belajar yang ingin dicapai dalam penelitian ini adalah meningkatnya nilai keaktifan belajar yang cukup menjadi baik baik. Kategori keaktifan belajar berdasarkan kenaikan jumlah siswa yang keaktifan belajarnya memiliki predikat baik sebanyak $86 \%$ atau 12 siswa, dan nilai rerata keaktifan belajar (melakukan latihan) mencapai minimal 85.

\section{Keterampilan Bermain Tenis Meja}

Target yang diharapkan minimal ketuntasan belajar dan rerata di atas KKM pada kondisi akhir (akhir siklus II) . Indikator tercapai apabila keterampilan siswa bermain tenis meja mencapai $80 \%$ siswa tuntas belajar dengan nilai rerata minimal 85. Kriteria Ketuntasan Minimal (KKM) pada buku penyusunan kurikulum SDN 6 Baturetno menunjukkan KD 6.2 Mempraktikkan variasi teknik dasar ke dalam modifikasi permainan bola kecil serta nilai kerjasama, sportivitas dan kejujuran sebesar 75. Siswa dikatakan tuntas belajar jika berhasil mencapai aspek keterampilan dalam permainan bola kecil (tenis meja) apabila nilai yang diperoleh sesuai dengan KKM atau lebih besar dari KKM tersebut dalam kategori baik. Keberhasilan klasikal keterampilan bermain tenis meja mencapai $80 \%$ siswa tuntas dengan nilai rata-rata kelas sebesar 85.

\section{HASIL PENELITIAN DAN PEMBAHASAN Hasil Penelitian Deskripsi Pra Siklus}

Berdasarkan hasil pengamatan aktivitas kegiatan siswa dapat dilaporkan dalam bentuk rekapitulasi yang disajikan dalam tabel berikut:

Tabel 1. Rekapitulasi Hasil Penilaian Aktivitas Belajar Siswa Pra Siklus

\begin{tabular}{|c|c|c|c|c|c|}
\hline No. & $\begin{array}{c}\text { Interval Konversi } \\
\text { nilai }\end{array}$ & Klasifikasi & Predikat & Frek & $\begin{array}{c}\text { Persentase } \\
(\%)\end{array}$ \\
\hline 1. & $87,5 \leq \mathrm{A}<100$ & sangat Aktif & A & 1 & $4,76 \%$ \\
\hline 2. & $75 \leq \mathrm{B}<87,5$ & Aktif & B & 7 & $33,33 \%$ \\
\hline 3. & $62.5 \leq \mathrm{C}<75$ & cukup aktif & $\mathrm{C}$ & 4 & $19,05 \%$ \\
\hline 4. & $\mathrm{D}<62,5$ & Kurang aktif & D & 9 & $42,86 \%$ \\
\hline & Rata-rata & & \multicolumn{5}{|c|}{64,96 (cukup aktif/C) } \\
\hline
\end{tabular}

Dari rekapitulasi nilai aktivitas belajar siswa di atas dapat dideskripsikan bahwa siswa yang memiliki predikat A (sangat aktif) sebanyak 1 siswa atau 4,76 $\%$, siswa yang memiliki predikat $\mathrm{B}$ atau aktif sebanyak 7 siswa $(33,33 \%)$, siswa yang cukup aktif sebanyak 4 siswa $(19,05 \%)$, dan siswa yang kurang aktif sebanyak 9 siswa $(42,86 \%)$, dengan rata- 
rata keaktifan belajar siswa sebesar 64,96 yaitu termasuk dalam kategori cukup aktif (C). Kondisi proses pembelajaran dalam kategori cukup masih perlu ditingkatkan karena dari catatan lapangan masih ditemukan adanya beberapa siswa yang dalam melakukan praktik bermain tenis masih takut kalau salah sehingga semuan hanya mengangantungkan pada contoh guru tanpa ada keberanian untuk berlatih sendiri. Selain itu ada juga siswa yang malas berlatih karena kurang berminat dengan permainan tenis meja. Hal ini dikarenakan proses pembelajaran hanya bersifat klasikal dan lebih banyak teori dari pada praktik atau berlatih.

Selanjutnya, peneliti melakukan pengamatan pada keterampilan tenis meja yang dimiliki oleh subjek penelitian. Hasil pengamatan pada tahap pra siklus dapat dilihat pada rekapitulasi nilai keterampilan bermain tenis meja pra siklus berikut:

Tabel 2. Rekapitulasi Nilai Keterampilan Bermain Tenes Meja Pra Siklus

\begin{tabular}{|c|c|c|c|c|c|}
\hline No. & $\begin{array}{c}\text { Interval } \\
\text { Konversi nilai }\end{array}$ & Klasifikasi & Predikat & Frekuensi & $\begin{array}{c}\text { Persentase } \\
(\%)\end{array}$ \\
\hline 1. & $87,5 \leq \mathrm{A}<100$ & $\mathrm{~A}$ & 0 & $0,00 \%$ & $87,5 \leq \mathrm{A}<100$ \\
\hline 2. & $75 \leq \mathrm{B}<87,5$ & $\mathrm{~B}$ & 8 & $38,10 \%$ & $75 \leq \mathrm{B}<87,5$ \\
\hline 3. & $62.5 \leq \mathrm{C}<75$ & $\mathrm{C}$ & 0 & $0 \%$ & $62.5 \leq \mathrm{C}<75$ \\
\hline 4. & $\mathrm{D}<62,5$ & $\mathrm{D}$ & 13 & $61,90 \%$ & $\mathrm{D}<62,5$ \\
\hline \multicolumn{2}{|c|}{ Jumlah } & & \multicolumn{4}{|c|}{21} \\
\hline & Rata-rata & & \multicolumn{3}{|c|}{61,43 (Kategori kurang) D } \\
\hline & Tuntas & & \multicolumn{4}{c|}{13} \\
\hline \multicolumn{2}{|c|}{ Tidak Tuntas } & & \multicolumn{4}{|c|}{} \\
\hline
\end{tabular}

Dari tabel 2 dapat dideskripsikan bahwa keterampilan bermain tenis meja pada prasiklus belum ada siswa (0siswa) atau $0 \%$ yang mendapat nilai dengan predikat sangat baik (A), yang mendapat nilai dengan predikat baik (B) sebanyak 8 siswa atau $38,10 \%$, yang mendapat nilia dengan predikat cukup (C) sebanyak 0 siswa atau $0 \%$ dan yang mendapat niai dengan predikat kurang baik /perlu bimbingan sebanyak 13 siswa atau 61,9\%. Dengan demikian jumlah siswa yang tuntas belajar sebanyak 8 siswa atau 38,1\% dan yang belum tuntas belajar sebanyak 13 siswa atau $61,9 \%$, dengan nilai rata-rata
61,43 yaitu masuk pada kategori kurang atau perlu bimbingan (D).

Dilihat dari perolehan nilai masingmasing aspek, dapat diketahui aspek terendah pada aspek kerja kaki. Rata-rata nilai kerja kaki baru mencapai 53,6 . Ini menunjukkan bahwa siswa belum terampil melakukan kerja kaki dengan benar. Masih banyak siswa yang gerakan kakinya sembarangan dan tidak terarah. Demikian juga pada aspek memegang bad, masih banyak ditemukan siswa yang belum benar dalam memegang bet sehingga menghasilkan pukulan yang kurang tepat, oleh karenanya pada aspek pukulan pun rata-rata nilai siswa masih rendah atau memerlukan bimbingan.

\section{Pembahasan \\ Deskripsi Siklus I}

Pelaksanaan tindakan siklus I dilaksanakan pada minggu ke 3 dan ke 4 bulan Agustus 2019. Pelaksanaan tindakan pada siklus 1 menerapkan metode latihan yang dilakukan secara beregu dengan media dinding/tembok dilakukan. Pada siklus 1 evaluasi yang dilakukan adalah melakukan : (1) pegangan (grip), (2) sikap atau posisi bermain (stance), (3) teknik memukul (stroke), (4) kerja kaki (footwork); (5) teknik servis. Tujuannya agar siswa bisa lebih terampil dalam bermain tenes meja, adapun pelaksanaannya dilaksanakan dalam 2 kali pertemuan. Pertemuan ke 1 dilaksanakan pada hari Selasa tanggal 13 Agustus2019 untuk melaksanakan latihan dan pertemuan ke 2 dilaksanakan pada hari Selasa tanggal 20 Agustus 2019 untuk pengambilan nilai atau tes.

a. Keterampilan Bermain Tenis Meja Siklus I

Setelah dilaksanakan tindakan pada siklus I, Peneliti melakukan penilaian terhadap keterampilan bermain tenis meja pada subjek penelitian. Berikut merupakan tabel rekapitulasi hasil penilaian 
keterampilan bermain tenis meja pada siklus I :

Tabel 3. Rekapitulasi Hasil Penilaian Keterampilan Bermain Tenes Meja Siklus I

\begin{tabular}{|c|c|c|c|c|}
\hline No. & Interval & Predikat & Frekuensi & Persentase (\%) \\
\hline 1. & $87,5 \leq \mathrm{A}<100$ & $\mathrm{~A}$ & 0 & $0,00 \%$ \\
\hline 2. & $75 \leq \mathrm{B}<87,5$ & $\mathrm{~B}$ & 15 & $71,4 \%$ \\
\hline 3. & $62.5 \leq \mathrm{C}<75$ & $\mathrm{C}$ & 6 & 28,6 \\
\hline 4. & $\mathrm{D}<62,5$ & $\mathrm{D}$ & 0 & $0 \%$ \\
\hline \multicolumn{2}{|c|}{ Jumlah } & & 21 & $100 \%$ \\
\hline Rata-rata & & 76,43 & Kategori baik (B) \\
\hline \multicolumn{2}{|c|}{ Tuntas } & & 15 & $71,4 \%$ \\
\hline \multicolumn{2}{|c|}{ Tidak Tuntas } & & 6 & 28,6 \\
\hline
\end{tabular}

Dari tabel tersebut dapat dideskripsikan bahwa keterampilan bermain tenis meja pada siklus I belum ada siswa (0) atau 0\% yang mendapat nilai dengan predikat sangat baik (A), yang mendapat nilai dengan predikat baik (B) sebanyak 15 siswa atau 71,4\%, yang mendapat nilia dengan predikat cukup (C) sebanyak 0 siswa atau $0 \%$ dan yang mendapat nilai dengan predikat kurang baik /perlu bimbingan sebanyak 6 siswa atau $28,6 \%$. Dengan demikian jumlah siswa yang tuntas belajar sebanyak 15 siswa atau $71,4 \%$ dan yang belum tuntas belajar sebanyak 6 siswa atau 28,6\%, dengan nilai rata-rata 76,43 yaitu masuk pada kategori cukup (C).

Dilihat dari perolehan nilai masingmasing aspek, dapat diketahui aspek terendah pada aspek posisi bermain. Ratarata nilai kerja kaki baru mencapai 70,2 atau dalam kategori cukup. Ini menunjukkan bahwa siswa belum terampil melakukan posisi yang benar dalam bermain tenes meja. Masih ada beberapa siswa yang posisi bermainnya kurang benar. Demikian juga pada aspek posisi pukulan, masih banyak ditemukan siswa yang belum benar dalam melakukan pukulan sehingga menghasilkan pukulan yang kurang tepat, oleh karenanya pada aspek pukulan pun rata-rata nilai siswa masih belum mencapai kategori baik dan memerlukan latihan lagi. b. Aktifitas Belajar Siswa

Selama proses pembelajaran guru mengadakan pengamatan tentang keaktifan siswa dalam mengikuti proses pembelajaran/ melakukan latihan yakni ketika melakukan gerakan-gerakan pemanasan sampai dengan praktik memainkan bola tenis. Pengamatan dilakukan dengan menggunakan lembar instrumen pengamatan yang telah dipersiapkan. Berdasarkan hasil pengamatan aktivitas kegiatan siswa dapat dilaporkan dalam bentuk rekapitulasi yang disajikan dalam tabel berikut.

Tabel 4. Rekapitulasi Hasil Penilaian Keaktifan Belajar Siswa Siklus I

\begin{tabular}{|c|c|c|c|c|c|}
\hline No. & $\begin{array}{c}\text { Interval } \\
\text { Konversi nilai }\end{array}$ & Klasifikasi & Predikat & Frekuensi & $\begin{array}{c}\text { Persentase } \\
(\%)\end{array}$ \\
\hline 1. & $87,5 \leq A<100$ & $\begin{array}{l}\text { sangat } \\
\text { Aktif }\end{array}$ & A & 4 & $19,05 \%$ \\
\hline 2. & $75 \leq B<87,5$ & Aktif & B & 11 & $52,38 \%$ \\
\hline 3. & $62.5 \leq \mathrm{C}<75$ & cukup aktif & $\mathrm{C}$ & 6 & $28.57 \%$ \\
\hline 4. & $\mathrm{D}<62,5$ & $\begin{array}{l}\text { Kurang } \\
\text { aktif }\end{array}$ & D & 0 & $0 \%$ \\
\hline & Rata-rata & & \multicolumn{3}{|c|}{ 79,92 (aktif/ B) } \\
\hline
\end{tabular}

Dari rekapitulasi nilai aktivitas belajar siswa di atas dapat dideskripsikan bahwa siswa yang memiliki predikat A (sangat aktif) sebanyak 4 siswa atau 19,05 $\%$, siswa yang memiliki predikat $\mathrm{B}$ atau aktif sebanyak 11 siswa atau 52,38\% , siswa yang cukup aktif sebanyak 6 siswa atau $28.57 \%$, dan siswa yang kurang aktif sebanyak 0 siswa atau 0\% dengan ratarata keaktifan belajar siswa sebesar 79,92 yaitu termasuk dalam kategori aktif (B).

Dari data tersebut menunjukkan bahwa proses pembelajaran belum bisa membangkitkan aktivitas belajar siswa dengan baik. Kurang aktifnya belajar siswa dapat dilihat dari catatan lapangan yang menunjukkan masih adanya beberapa siswa yang dalam melakukan latihan kurang percaya diri dan takut salah.

Proses pembelajaran pada siklus I yang dilaksanakan secara beregu belum dengan durasi latihan 15 menit sudah dapat membawa perubahan meningkatknya hasil belajar siswa namun belum 
mencapai hasil sesuai harapan. Hal ini disebabkan dengan cara beregu masingmasing 4 siswa dan ada yang 5 siswa, siswa kurang serius karena merasa kurang mandiri. Apalagi didapat beberapa siswa yang tidak berani melakukan permainan tenes meja dikarenakan rasa takut bersalah, menjadikan hasil belajar siswa kurang optimal. Oleh karena itu maka perlu dilakukan perbaikan proses pembelajaran pada siklus II

\section{Deskripsi Siklus II}

Pelaksanaan tindakan siklus II dilaksanakan pada minggu ke 1 dan ke 2 bulan September 2019. Pelaksanaan tindakan pada siklus 2 menerapkan metode latihan dengan media meja pingpong yang dilaksanakan secara berpasangan dengan teknis kompetisi. Pada siklus 2 evaluasi yang dilakukan adalah melakukan : (1) pegangan (grip), (2) sikap atau posisi bermain (stance), (3) teknik memukul (stroke), (4) kerja kaki (footwork); (5) teknik servis. Tujuannya agar siswa bisa lebih terampil dalam bermain tenes meja.

Pada siklus II dilaksanakan dalam 2 kali pertemuan. Pertemuan pertama dilaksanakan pada hari Selasa tanggal 3 September 2019. Evaluasi pada pertemuan 1 difokuskan pada aktifitas siswa melakukan latihan pemanasan, latihan inti dan latihan pendinginan, dengan cara observasi yang dicatat pad lembar observasi dan hasilnya untuk mengetahui peningkatan proses pembelajaran. Sedangkan pertemuan ke 2 dilaksanakan hari Selasa tanggal 10 September 2019. Evaluasi pada pertemuan 2 difokuskan pada keterampilan melakukan permainan tenis meja.

a. Keterampilan Bermain Tenis Meja Siklus II

Setelah dilaksanakan tindakan pada siklus II, Peneliti melakukan penilaian terhadap keterampilan bermain tenis meja pada subjek penelitian. Berikut merupakan tabel rekapitulasi hasil penilaian keterampilan bermain tenis meja pada siklus II :

Tabel 5. Rekapitulasi Hasil Penilaian Keterampilan Bermain Tenes Meja Siklus I

\begin{tabular}{|c|c|c|c|c|}
\hline No. & Interval & Predikat & Frekuensi & Persentase (\%) \\
\hline 1. & $87,5 \leq \mathrm{A}<100$ & $\mathrm{~A}$ & 12 & $57,1 \%$ \\
\hline 2. & $75 \leq \mathrm{B}<87,5$ & $\mathrm{~B}$ & 6 & $28,6 \%$ \\
\hline 3. & $62.5 \leq \mathrm{C}<75$ & $\mathrm{C}$ & 3 & $14,3 \%$ \\
\hline 4. & $\mathrm{D}<62,5$ & $\mathrm{D}$ & 0 & $0 \%$ \\
\hline \multicolumn{2}{|c|}{ Jumlah } & & 21 & $100 \%$ \\
\hline Rata-rata & & 87,14 & Baik (B) \\
\hline \multicolumn{2}{|c|}{ Tuntas } & & 18 & $85,7 \%$ \\
\hline \multicolumn{2}{|c|}{ Tidak Tuntas } & & 3 & $14,3 \%$ \\
\hline
\end{tabular}

Dari tabel tersebut dapat dideskripsikan bahwa keterampilan bermain tenis meja pada siklus siswa yang mendapat nilai dengan predikat sangat baik (A) sebanyak 12 siswa atau 57,1\%, yang mendapat nilai dengan predikat baik (B) sebanyak 6 siswa atau 28,6\%, yang mendapat nilia dengan predikat cukup (C) sebanyak 3 siswa atau 14,3\% dan yang mendapat niai dengan predikat kurang baik /perlu bimbingan sebanyak 0 siswa atau $0 \%$. Dengan demikian jumlah siswa yang tuntas belajar sebanyak 18 siswa atau $85,7 \%$ dan yang belum tuntas belajar sebanyak 3 siswa atau 14,3\%, dengan nilai rata-rata 87.14 yaitu masuk pada kategori baik (B). Dilihat dari perolehan nilai masing-masing aspek, dapat diketahui bahwa semua aspek sudah dapat dikuasai dengan baik. Ini menunjukkan bahwa siswa sudah terampil melakukan semua gerakan tenes meja dengan baik dan benar

\section{b. Aktifitas Belajar Siswa}

Selama proses pembelajaran guru mengadakan pengamatan tentang keaktifan siswa dalam mengikuti proses pembelajaran/ melakukan latihan yakni ketika melakukan gerakan-gerakan pemanasan sampai dengan praktik memainkan bola tenis. Pengamatan dilakukan dengan menggunakan lembar instrumen pengamatan yang telah 
dipersiapkan.

Berdasarkan hasil pengamatan aktivitas kegiatan siswa dapat dilaporkan dalam bentuk rekapitulasi yang disajikan dalam tabel berikut:

Tabel 6. Rekapitulasi Hasil Penilaian Keaktifan Belajar Siswa Siklus I

\begin{tabular}{|l|c|c|c|c|c|}
\hline No. & $\begin{array}{c}\text { Interval } \\
\text { Konversi nilai }\end{array}$ & $\begin{array}{c}\text { Klasifikasi } \\
\text { Kangat }\end{array}$ & Predikat & Frekuensi & $\begin{array}{c}\text { Persentase } \\
(\%)\end{array}$ \\
\hline 1. & $87,5 \leq \mathrm{A}<100$ & $\begin{array}{c}\text { saktif } \\
\text { A }\end{array}$ & A & 13 & $61,9 \%$ \\
\hline 2. & $75 \leq \mathrm{B}<87,5$ & Aktif & B & 8 & $38,1 \%$ \\
\hline 3. & $62.5 \leq \mathrm{C}<75$ & cukup aktif & $\mathrm{C}$ & 0 & $0 \%$ \\
\hline 4. & $\mathrm{D}<62,5$ & $\begin{array}{c}\text { Kurang } \\
\text { aktif }\end{array}$ & $\mathrm{D}$ & 0 & $0 \%$ \\
\hline & Rata-rata & \multicolumn{3}{|c|}{87,95 (sangat aktif/ A) } \\
\hline
\end{tabular}

Dari rekapitulasi nilai aktivitas belajar siswa di atas dapat dideskripsikan bahwa siswa yang memiliki predikat A (sangat aktif) sebanyak 13 siswa atau 61,9 $\%$, siswa yang memiliki predikat B atau aktif sebanyak 8 siswa atau $38,1 \%$, siswa yang cukup aktif sebanyak 0 siswa atau 0 $\%$, dan siswa yang kurang aktif sebanyak 0 siswa atau 0\% dengan rata-rata keaktifan belajar siswa sebesar 87,9 yaitu termasuk dalam kategori sangat aktif (A). Dari hasil penilaian keterampilan siswa bermain tenes meja,pada siklus II telah mencapai tingkat ketuntasan $85,7 \%$ atau 18 siswa tuntas belajar, dengan rata-rata nilai hasil belajar sebesar 87,14 dalam kategori sangat baik. Hal ini telah menunjukukkan ketercapaian indicator kinerja yang ditentukan.

Berdasarkan hasil pengamatan tentang aktifitas belajar siswa dalam mengikuti proses pembelajaran menunjukkan jumlah siswa yang sangat aktif belajar sebanyak 12 siswa $(57,14 \%)$, siswa yang aktif belajar sebanyak 9 siswa $(42,86 \%)$, dengan nilai rata-rata 87,95 , sudah mencapai indicator kinerja yang ditentukan. Dengan demikian karena sampai pada siklus II penelitian ini telah mencapai indicator kinerja yang ditentukan maka penelitian ini tidak dilanjutkan lagi ke siklus selanjutnya.

\section{KESIMPULAN}

Berdasarkan data dari hasil penelitian ini, maka dapat disimpulkan bahwa metode berlatih dapat meningkatkan keterampilan bermain tenis meja pada siswa kelas VI SD Negeri 6 Baturetno semester 1 Tahun Pelajaran 2019/2020.

\section{DAFTAR PUSTAKA}

A.M Bandi Utama dkk. (2004). Kemampuan Bermain Tenis Meja, Studi Kondisi Antara Kelincahan dan Kemampuan Pukulan Dengan Kemampuan Bermain Tenis Meja. Laporan Penelitian Yogyakarta: FIK UNY

Ahmad Rohani. 2004. Pengelolaan Pengajaran. Remaja Rosdakarya.

Ahmad Subagyo,2008 . Studi Kelayakan Teori dan Aplikasi, Jakarta: PT. Gramedia. Anoraga, Dimyati dan Mujiyono. 2006. Belajar dan Pembelajaran. Jakarta: RIneka Cipta

Djamarah, Syaiful Bahri. 2000. Strategi Belajar Mengajar. Jakarta: Rineksa Cipta

Edward L. Fok. 1988. The Physiologycal Bases of Physical Education and Athletics, New York: Holt Wb Sounders Company

Hamalik.2006. Proses Belajar Mengajar. Bandung: Bumi Aksara

Larry, Hodges. (2007). Tenis Meja Tingkat Pemula. Jakarta: PT Raja Grafindo Persada.

M. Frank Verducy. 1980. Measurement Concept in Physical Education. St. Louis Missouri: Mosby Company

Muhajir. (2006). Pendidikan Jasmani, Olahraga dan Kesehatan. SMA kelas. XII. Penerbit Erlangga

Sudjana. 2010. Dasar-dasar Proses Belajar Mengajar. Bandung:Sinar Baru Algesindo Sutarmin. (2007). Terampil Berolahraga Tenis Meja. Surakarta: Era Intermedia. 
Suwaji. PTK. 2013.Peningkatan Keterampilan Berman Sepak Bola Melalui Drill Method Kelas V SDN 3 Belikurip. Perpustakaan SDN 3 Belikurip (tidak dipublikasikan)

Tomoliyus. (2012). Panduan Kepelatihan Tenis Meja Bagi Siswa Sekolah Dasar. Disajikan dalam Rangka Pembinaan Klub Olahraga Sekolah Dasar SeIndonesia Tahap ii Di Yogyakarta.

UU Republik Indonesia Nomor 20 tahun 2008 tentang Sistem Pendidikan Nasional. Jakarta : Depdiknas. 